\title{
Deteksi Gen SHV pada Isolat Klinik Escherichia coli Penghasil Extended Spectrum Beta-Lactamases (ESBLs) dari Urin Pasien di RSUD Dr. Soetomo Surabaya
}

\author{
Yulianto Ade Prasetya \\ Program Studi Teknologi Laboratorium Medik, STIKes RS Anwar Medika, Jalan Raya By Pass Krian Km. 33, \\ Sidoarjo, 61263 \\ yuliantoadeprasetya@gmail.com
}

\begin{abstract}
ESBLs of Eschericia coli responsible for the occurance of outbreaks nosocomial infection, increased morbidity, and mortality as well as the increase in health costs. The purpose of the research to detection of SHV gene in Eschericia coli clinical isolates produce ESBLs, which is a collection of Clinical Microbiology Laboratory RSUD Dr. Soetomo Surabaya in January-February 2014 from urine of patients. The kind of research that we use is observational descriptive with the approach genotype molecule. The methods used for the detection of genotypic by (Polymerase Chain Reaction) PCR thus electrophoresis and visualized on agarose gel $1.5 \%$. The results of research on the genes ESBL using PCR show than thirthy isolates show that the twelve (40\%) isolate positive containing a gene SHV.
\end{abstract}

Keywords: ESBLs, Escherichia coli, RSUD Dr. Soetomo Surabaya, SHV

\begin{abstract}
Abstrak
Esherichia coli ESBLs bertanggungjawab terhadap terjadinya wabah infeksi nosokomial, peningkatan morbiditas dan mortalitas, serta peningkatan biaya kesehatan. Tujuan penelitian ini yakni untuk mendeteksi keberadaan gen SHV pada isolat klinik E.coli penghasil ESBLs dari urine pasien yang merupakan koleksi Laboratorium Mikrobiologi Klinik RSUD Dr. Soetomo Surabaya pada bulan Januari - Februari 2014. Jenis penelitian yang digunakan adalah observasional deskriptif dengan pendekatan molekul genetik. Metode yang digunakan untuk deteksi gen SHV menggunakan PCR (Polymerase Chain Reaction) kemudian dielektroforesis dan divisualisasikan pada gel agarose 1.5\%. Hasil penelitian menunjukkan bahwa dari tiga puluh isolat, sebanyak dua belas isolat (40\%) positif mengandung gen SHV.
\end{abstract}

Kata kunci: ESBLs, Escherichia coli, RSUD Dr. Soetomo Surabaya, SHV

\section{Pendahuluan}

Extended Spectrum Beta Lactamases (ESBLs) merupakan enzim yang dikode oleh gen yang sebagian besar terdapat di plasmid yang dapat menghidrolisis antibiotik sefalosporin generasi ketiga dan keempat serta monobaktam (aztreonam) (Sharma et. al., 2010; Patterson, 2010). Colodner (2013) menyatakan bahwa E. coli merupakan kelompok Enterobacteriaceae yang paling banyak menghasilkan ESBLs. Escherichia coli termasuk patogen oppurtunistik yang selalu menunjukkan peningkatan resistensi terhadap berbagai antibiotik. Bakteri ini menduduki insidensi tertinggi penyebab urinary tract infections (UTIs) (Jan et. al., 2009). Salah satu gen pengkode ESBLs yang paling banyak ditemukan yakni SHV. Pada gen ini terjadi subtitusi asam amino posisi 238 dan 240 sehingga menyebabkan resistensi terhadap sefotaksim dan seftazidim (Garza et.al, 2007).

Escherichia coli penghasil ESBLs dari RSUD Dr. Soetomo Surabaya telah berhasil diidentifikasi dan dikonfirmasi secara fenotipik menggunakan DDST (Double Disk Synergy Test) dan perangkat Phoenix. Sebanyak tiga 
puluh isolat E.coli penghasil ESBLs ditemukan di berbagai ruang yakni Ruang Interna, Anak, Instalasi Rawat Jalan (IRJ), Bedah, Paru, Jiwa, Kulit, dan Saraf. Selain secara fenotipik, identifikasi bakteri penghasil ESBLs secara genotipik penting dilakukan untuk mendeteksi subtipe ESBLs dan memudahkan pemberian antibiotik secara efektif dan efisien. Penelitian ini bertujuan untuk mendeteksi gen SHV pada isolat klinik E.coli penghasil ESBLs di berbagai ruang RSUD Dr. Soetomo Surabaya.

\section{Metode Penelitian}

\section{Persiapan panen sel}

Isolat klinik E.coli yang digunakan berasal dari urin pasien yang merupakan koleksi Laboratorium Mikrobiologi Klinik RSUD Dr. Soetomo Surabaya pada bulan Januari- Februari 2014. Isolat klinik E.coli diinokulasikan ke medium MHA (Mueller Hinton Agar) yang mengandung sefotaksim $0.002 \mathrm{mg} / \mathrm{ml}$ dan diinkubasi selama 24 jam suhu $37^{\circ} \mathrm{C}$. Satu ose koloni yang tumbuh disuspensikan dengan $0.1 \mathrm{ml}$ aquadest steril dalam mikrotube dan diinkubasi dalam hot plate suhu $100^{\circ} \mathrm{C}$ selama 5 menit. Sel kemudian disentrifugasi $100 \mathrm{rpm}$ selama 5 menit pada suhu ruang. Supernatan diambil sebanyak $15 \mu \mathrm{l}$ dan digunakan sebagai DNA template untuk amplifikasi.

\section{Amplifikasi gen SHV}

Sebanyak $5 \mu$ template dicampur dengan 25 $\mu \mathrm{l}$ campuran reaksi PCR (0.5 U Taq Polymerase, $0.2 \mathrm{mM} \mathrm{dNTP}, 1.5 \mathrm{mM} \mathrm{MgCl}_{2}$, Buffer 1X, dan $1.25 \mu \mathrm{l}$ primer). Primer spesifik yang digunakan yakni 5'GGTTATGCGTTATTCGCC3' \& 5'TTAGGTTGCCAGTGCTC3'(Ferreira et al., 2011). Kondisi PCR yang digunakan yaitu: denaturasi awal pada suhu $94^{\circ} \mathrm{C}$ selama 7 menit kemudian diikuti dengan 35 siklus yang terdiri dari $96{ }^{\circ} \mathrm{C}$ selama 50 detik (denaturasi), $50{ }^{\circ} \mathrm{C}$ selama 40 detik (annealing), dan $72{ }^{\circ} \mathrm{C}$ selama 1 menit (ekstensi) dan diikuti dengan ekstensi akhir pada suhu $72{ }^{\circ} \mathrm{C}$ selama 10 menit. Produk hasil PCR divisualisasikan dalam $1.5 \%$ gel agarose kemudian dilakukan elektroforesis pada voltase 100 selama 60 menit. Pita DNA yang terbentuk diamati dengan bantuan $U V$ Transilluminator panjang gelombang $360 \mathrm{~nm}$.

\section{Hasil dan Pembahasan}

Sebanyak $43.33 \%$ isolat yang digunakan paling banyak berasal dari ruang Interna sedangkan $16.67 \%$ berasal dari ruang Instalasi Rawat Jalan (IRJ) (Tabel 1). Sampel urin yang mengandung E.coli digunakan karena paling banyak menghasilkan ESBLs dilihat dari data tahun 2005 yang menunjukkan sebanyak $61.7 \%$ E.coli penghasil ESBLs berasal dari urin (Severin et al., 2010) sedangkan tahun 2011 ditemukan sebanyak 26.5\% (Kuntaman et.al., 2011). Foxman (2010) menyebutkan bahwa UTIs merupakan infeksi yang paling sering disebabkan oleh E.coli sebesar $70-95 \%$ pada infeksi komunitas dan $50 \%$ pada infeksi nosokomial.

Penambahan sefotaksim pada medium dimaksudkan untuk menstimulasi plasmid dari E.coli penghasil ESBL, dimana gen pengkode ESBL paling banyak ditemukan di plasmid terutama plasmid R. Hasil visualisasi amplifikasi PCR (Gambar 1) menunjukkan bahwa sebesar 40\% (12/30) E.coli penghasil ESBLs mengandung gen SHV. Persentase ini meningkat bila dibandingkan dengan penelitian sebelumnya tahun 2005 yakni sebesar $4.1 \%$ pada SHV-1 dan $1.4 \%$ pada SHV-12 (Severin et. al., 2005). Beberapa negara juga bervariasi presentasenya kehadiran gen SHV pada E.coli penghasil ESBLs yakni di Thailand 3.8\% (Kirastin et.al., 2008) dan Mexico sebesar 35.7\% (Garzo et.al., 2007).

Data penelitian ini juga menunjukkan bahwa gen SHV pada E.coli penghasil ESBLs ditemukan paling banyak di ruang Instalasi Rawat Jalan (IRJ) (Tabel 1) yakni empat isolat sedangkan isolat lain ditemukan di ruang Interna (3 isolat), Ruang Paru (3 isolat), dan Ruang Anak (2 isolat). Penelitian lain menunjukkan bahwa isolat E.coli yang mengandung SHV banyak ditemukan di ruang IGD (Instalasai Gawat Darurat, Traumatologi, dan Bedah (Sorlozano et al., 2007). 


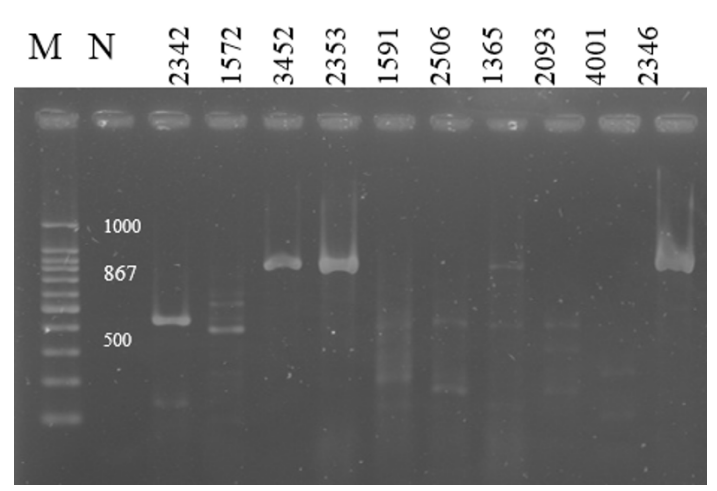

Gambar 1. Hasil PCR gen SHV dengan amplikon sebesar 867 bp

\begin{tabular}{ccc}
\hline Ruang & $\begin{array}{c}\text { Jumlah } \\
\text { isolat (\%) }\end{array}$ & $\begin{array}{c}\text { Gen SHV } \\
\mathbf{( \% )}\end{array}$ \\
\hline Interna & $13(43.33)$ & $3(25 \%)$ \\
Anak & $4(13.34)$ & $2(17 \%)$ \\
IRJ & $5(16.67)$ & $4(33 \%)$ \\
Bedah & $1(3.33)$ & - \\
Paru & $4(13.34)$ & $3(25 \%)$ \\
Jiwa & $1(3.33)$ & - \\
Kulit & $1(3.33)$ & - \\
Saraf & $1(3.33)$ & - \\
TOTAL & 30 & 12 \\
\hline
\end{tabular}

Perbedaan jumlah ini dapat disebabkan penggunaan antibiotik yang berbeda pada masing-masing ruang perawatan. Penggunaan antibiotik sefalosporin generasi ketiga, antibiotik golongan beta laktam, dan antibiotik golongan floroquinolon di rumah sakit diduga menjadi faktor resiko munculnya bakteri penghasil ESBLs. Selain itu, penggunaan antibiotik pada komunitas turut berperan dalam penyebaran gen resisten diantara spesies bakteri (Adelyap et.al., 2011). Semakin tinggi penggunaan antibiotik yang tidak tepat, semakin tinggi pula tekanan selektif proses evolusi dan proliferasi strain mikroorganisme yang bersifat resisten (Pratiwi, 2008).

Sebanyak enam belas isolat yang tidak teridentifikasi gen SHV bukan berarti tidak menghasilkan ESBLs. Ada lebih dari 700 jenis ESBLs yang diklasifikasikan dalam empat grup yakni grup 1, grup 2 (2a-2f), grup 3a (B1 dan B2), dan grup 4. Kemungkinan isolat klinik E.coli penghasil ESBL yang tidak teridentifikasi gen SHV mengandung gen seperti TEM, CTX-M, atau CARB-2 (Bush \& Jacoby, 2010).

\section{Kesimpulan}

Berdasarkan identifikasi secara genotip menggunakan PCR sebanyak 40\% (12/30) isolat klinik E.coli penghasil ESBLs berhasil di deteksi dengan persebaran empat isolat $(33 \%)$ di Ruang Instalasi Rawat Jalan, tiga isolat (25\%) di Ruang Interna, tiga isolat (25\%) di Ruang Paru, dan dua isolat (17\%) di Ruang Anak.

\section{Daftar Pustaka}

Adelyap, M.A., Harbart, S., Vernaz, N., Kearney, M.P., Scott, M.G., Elhajji, F.W.D., Aldiab M.A dan Mc Elnay, J.C. 2011. The impact of antibiotic use on the incidence and resistance pattern of extended-spectrum beta-lactamase-producing bacteria in primary and secondary healthcare settings. British Journal of ClinicalPharmacology.DOI:10.1111/.1365-2125.

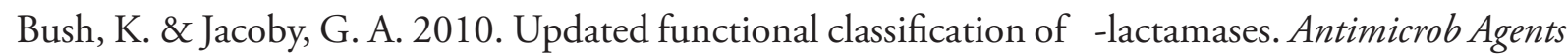
Chemother. 54: 969-976.

Colodner, R. 2013. Extended-Spectrum Beta-Lactamases: The End of Cephalosporins; http://www. ima.org.il/imaj/ar05may-13.pdf.

Ferreira, C.M., Ferreira, W. A., Almeida, N.O., Gomes, F., Naveca, and Barbosa, M.G. 2011. Extended-Spectrum Beta-Lactamase-Producing Bacteria Isolated From Hematologic Patients In Manaus, State Of Amazonas, Brazil. Brazilian Journal of Microbiology. 42: 1076-1084.

Foxman, B. 2010. The epidemiology of urinary tract infection. Nat Rev Urol 7(12): 653-660. 
Garza-Ramos, U., Martinez-Romero, E., and Silvia-Sanchez, J. 2007. SHV-type Extended spectrum B-lactamase (ESBL) are encoded in related plasmids from Enterobacteria clinical isolates from Mexico. Salud Publica Mex. 49(6): 415-421.

Jan, N., Sudhir, U., and Archana K. 2009. Plasmid profile analysis of multidrug resistant E.coli isolated from UTI patients of Nagpur City, India. Romanian Biotechnological Letters. 14 (5): 4635-4640.

Kiratisin, P., Apisarnthanarak, A., Laesripa, C., and Saifon, P. 2008. Molecular characterization and epidemiology of extended-spectrum ß-lactamase producing Escherichia coli and Klebsiella pneumoniae isolates causing health care-associated infection in Thailand, where the CTX-M family is endemic. Antimicrob Agents Chemother.52:2818-2824.

Kuntaman, K., Santoso, S., Wahjono, H., Mertaningsih, N.M., Lestrasi, E.S., Farida, H., Hapsari, R., Firmanti, S.C., Noorhamdani, A.S., Santosaningsih, D., Purwono, P.B., and Kusumaningrum, D. 2011. The sensitivity pattern of extended spectrum beta lactamaseproducing bacteria against six antibiotics that routinely used in clinical setting. J. Indon Med Assoc. 61(12): 482-486.

Paterson, D.L. 2010. Extended-Spectrum $\bigotimes$-Lactamases: a Clinical Update; downloaded at http:// www. ncbi.nlm. nih.gov/pmc/articles/PMC1265908/pdf/0016-05.

Pratiwi, S.T. 2008. Mikrobiologi Farmasi. Penerbit Erlangga. Jakarta.hlmn 151.

Severin, J.A., Mertaningsih, N.M., Kuntaman, K., Lestari,E.S., Purwanta, M., Toom, N.L., Duerink, D.O., Hadi, U., Belkum, A., Verbrugh, H.A. and Goessens, W.H. 2010. Molecular characterization of extended-spectrum $\bigotimes$-lactamases in clinical Escherichia coli and Klebsiella pneuomniae isolates from Surabaya, Indonesia. J. Antimicrob Chemother. 65: $465-469$

Sharma, J., Sharma, M and Ray, P. 2010. Detection of TEM \& SHV genes in Eschericia coli \& Klebsiella pneuomoniae isolates in a tertiary care hospital from India. Indian J Med Res. 132: 332-336.

Sorlozano, A., Guteirrez, J., Luna, J.D., Oteo, J., Liebena, J., Soto, M.J., and Piedrola, G. 2007. High presence of extended-spectrum $\bigotimes$-lactamases and resistance to quinolones in clinical isolates of Escherichia coli. Microbiological Research. 162: 347-354. 